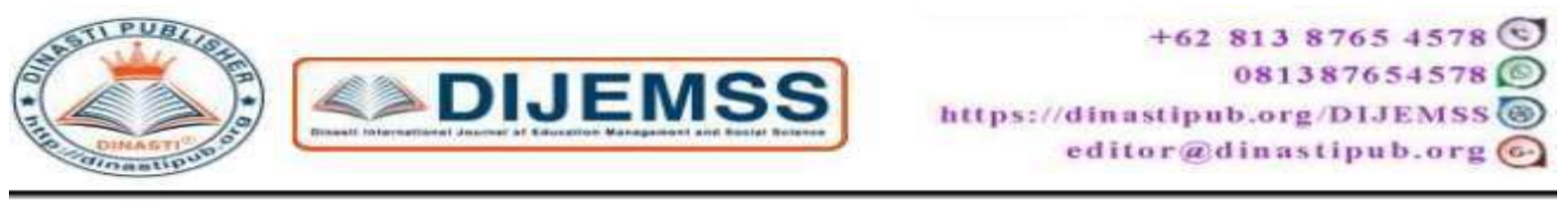

\title{
ABC ANALYSIS, FORECASTING AND ECONOMIC ORDER QUANTITY (EOQ) IMPLEMENTATION TO IMPROVE SMOOTH OPERATION PROCESS
}

\author{
Thukas Shilul Imarah ${ }^{1}$, Roni Jaelani ${ }^{2}$ \\ ${ }^{1)}$ Mercu Buana University, Jakarta, Indonesia \\ ${ }^{2)}$ Mercu Buana University, Jakarta, Indonesia
}

\begin{tabular}{|c|c|}
\hline $\begin{array}{l}\text { ARTICLE INFORMATION } \\
\text { Received: } 1 \text { February } 2020 \\
\text { Revised: } 7 \text { February } 2020 \\
\text { Issued: } 11 \text { February } 2020 \\
\text { Corresponding author: } \\
\text { Thukas Shilul Imarah } \\
\text { E-mail: } \\
\text { tukhas.shilul@ mercubuana.ac.id } \\
\text { roni_jaelani@yahoo.co.id }\end{array}$ & $\begin{array}{l}\text { Abstract: The study aims to test the effectiveness of } \\
\text { the implementation of several inventory control } \\
\text { methods to improve the smooth operation in a } \\
\text { trading company of industrial equipements } \\
\text { components that have difficulty in maintaining } \\
\text { inventory data accuracy, inventory shortages and in } \\
\text { other hand excess unrequired inventory. The research } \\
\text { data used is taken from the ERP report data and } \\
\text { manual reports created by the perpetrators of the } \\
\text { operational activities of the Inventory Control for the } \\
\text { period } 2016 \text { - 2018. The sampling method used is } \\
\text { purposive sampling of the product sales data in years } \\
\text { 2016 - 2018 as much as } 2498 \text { Stock Keeping Unit } \\
\text { (SKU) which is then processed using the method of } \\
\text { ABC analysis and FSN (Fast Moving, Slow Moving } \\
\text { and None Moving) analysis to get 10 SKUs that } \\
\text { belongs to the category A and F (Fast Moving) } \\
\text { group as a sample of research. The research method } \\
\text { uses the Quantitative method with the use of ABC } \\
\text { analysis, Forecasting and Economic Order Quantity. } \\
\text { The results shows that the implementation of ABC } \\
\text { analysis effectively reduced the workload of periodic } \\
\text { counting and is able to improve data accuracy to be } \\
\text { higher level. The exponential smoothing forecast } \\
\text { method shows the least gap to the actual value and } \\
\text { EOQ effectively optimizes ordering and holding } \\
\text { costs and reduces the risk of failure in Inventory } \\
\text { Control and positively affects the smoothness of the } \\
\text { operation process. } \\
\text { Keywords: Inventory Control, ABC analysis, } \\
\text { Perpetual Stock Check, Economic Order Quantity, } \\
\text { Forecasting. }\end{array}$ \\
\hline
\end{tabular}




\section{INTRODUCTION}

One of the competitive advantages that are expected to exist in a trading company is the inventory control to achieve the purpose of the right type availability and goods quantity at the right time and place according to the needs of sales. As a case study in a company moving in the field of trading industiral equipment components which Inventory Control has not been properly applied which had phenomenons:

1. At the end of August 2018 there were more than $20 \%$ pending delivery from shipment schedule due to lack of goods.

2. In October 2018 the accuracy of the inventory data was $79.7 \%$ and still there were $20,3 \%$ of the number of SKUs from all SKUs had not been verified.

3. In January 2019 the number of types of goods in the warehouse that do not move or not sold in the period of 12 month was $44 \%$ of all types of goods.

The analysis of the above phenomenons were caused by:

1. Difficulties of conducting periodic calculations regularly due to limited resource to calculate the large amount of Stock Keeper Units (SKUs).

2. The planning of need and purchase of supplies also has not been done well so that caused the shortage and the excess of inventory.

The aim of this study is to test the effectiveness of several ways of inventory management that can be applied to overcome the above phenomenon by:

Applying the method of Analysis $\mathrm{ABC}$ to reduce the difficulty of implementing perfetual Stock Check and improve the accuracy of inventory data.

Applying the most effective Forecasting Method for planning annual supplies need, Applying the Economic Order Quantity to improve the planning of purchasing supplies in higher level.

\section{LITERATURE REVIEW}

\section{The importance of Inventory Control}

According to Freddy Rangkuti $(2002,7)$ inventory will simplify and smoothing the company's operations in producing goods and then convey to the consumer. Inventory is useful to reduce the risk of good coming in delays, eliminate the risk of damaged goods, maintain the stability of the company's operations in reaching the optimal use of machinery and provide good service for consumers. According to Heizer et. AL $(2017,490)$ supplies are one of the most expensive assets of many companies and it can reach $50 \%$ or more of the invested capital so that good inventory control is crucial. According to Ahmad H. Sutawijaya and Eri Marlapa in Supply Chain Management: Analysis and application using Reference of SCOR published in the MIX: scientific journal of Management, Volume VI, No. 1, February 2016 mentioned that inventory management is also included in the SCOR (Supply Chain Operation Reference) model. Because it is included in the interactions in the supply chain of the company, whether it is interaction with suppliers and with consumers. Included in product transactions in the form of goods and services. And included in the interaction with the market to understand the "aggregate demand" until the fulfillment process of each order.

\section{Inventory Data Accuracy and Periodic Counting}

According to Heizer et. AL $(2017,493)$ the accuracy of inventory data is mandatory in inventory management, production planning and ultimately sales. Inventory data accuracy requires a continuous record of goods in and out of the warehouse as well as periodic calculations to remove inaccuracies between inventory data against the actual amount of inventory. 


\section{ABC Analysis}

According to Heizer et. al $(2017,491)$ the $\mathrm{ABC}$ analysis divides the inventory into three classifications based on the volume of the annual revenue value with the Pareto principle application. Category A is the item with the highest Rupiah value representing 70\% - $80 \%$ of the total volume of revenue and represents about $15 \%$ of the number of SKU. Category B is the item with annual Rupiah volume of about $15 \%-25 \%$ and representing about $30 \%$ of the number of SKU. Category C only representing 5\% of the annual Rupiah volume but covers about 55\% of the number of SKU. According to Freddy Rangkuti (2002, 21) the division of the grouping is not rigid based on three parts, sometimes it is dividing into four groups $(\mathrm{ABCD})$ or even more. For the purpose of goods management category A should receive maximum analysis because it is very high sales value and category $B$ attention number two underneath. While the category $\mathrm{C}$ should be analyzed in a casual fashion by taking into account one tendency, for example what kind of goods tend to increase sales, or have the highest inventory level and so on.

\section{Forecasting Need}

According to Heizer et. al (2017) there are two common approaches to forecasting needs i.e. quantitative approaches and qualitative approaches. A quantitative approach is a Time-Series model that predicting the assumption that the future is a function of the past.

1. The moving averages method is determined by simply summing the requests over the past 3 periods and divided by 3 .

Moving Average $=\frac{\sum \text { Demand in } \mathrm{n} \text { previous period }}{\mathrm{n} \text { (Number of periodes })}$

2. The Exponential Smoothing method is a weighty forecasting method of other moving averages involving only very small past data and is quite easy to use.

$\mathrm{F}_{\mathrm{t}}=\mathrm{F}_{\mathrm{t}-1}+\alpha\left(\mathrm{A}_{\mathrm{t}-1}-\mathrm{F}_{\mathrm{t}-1}\right)$

$\mathrm{F}_{\mathrm{t}}=$ Forecast

$\mathrm{F}_{\mathrm{t}-1}=$ Previous Forecast

$\alpha=$ Constant in range $0.05-0.50$

$\mathrm{A}_{\mathrm{t}-1}=$ Actual needs of the previous period

3. The Trend Projection method creates a trend line for a series of historical data and then projecting the slope of a future forecast line implementing the least-square method.

$\mathrm{y}=\mathrm{a}+\mathrm{bx}$

$\mathrm{a}=$ konstanta

$$
b=\frac{\sum x y-n \bar{x} \bar{y}}{\sum x^{2}-n \bar{x}^{2}}
$$

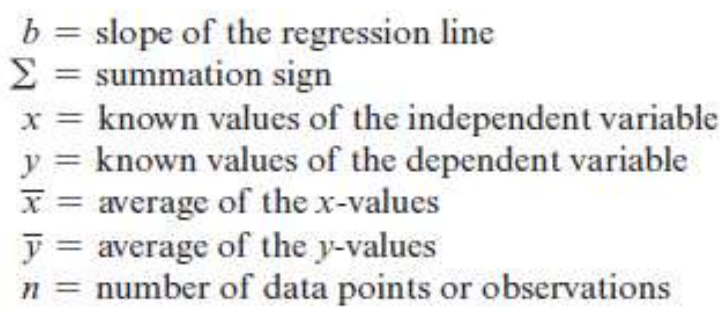

\section{Economic Order Quantity (EOQ)}


According to Freddy Rangkuti $(2002,11)$ effective inventory management must do the EOQ count for each purchase, calculate Safety Stock to anticipate the need to exceed the estimation and calculate Reorder Point to determine when making the booking in connection with the lead time. Economic Order Quantity (EOQ) model model considers setup (order) costs and holding costs.

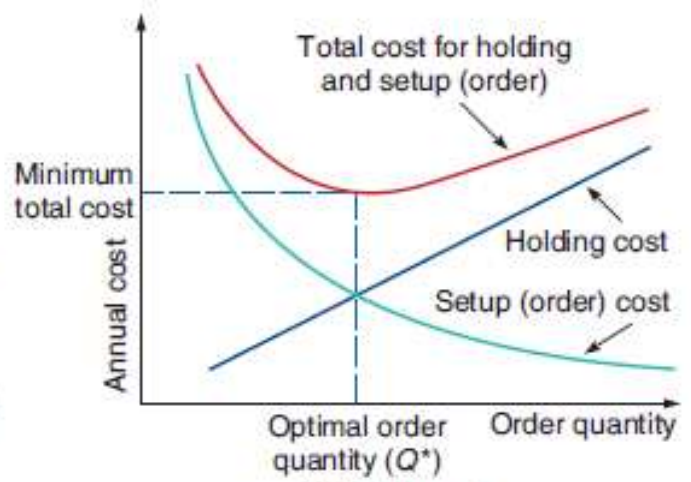

(c) Total costs

Figure 1. Cost as Purchase Amount Function

Source: Operations Management Sustainability and Supply Chain Management, Heizer et. al (2017)

The optimal order amount occurs at the point where the ordering cost curve and the holding cost curve intersect or in other words the optimal order amount will occur at the point where the total ordering cost is equal to the total holding cost. Using the following variables, we can specify the ordering cost and the holding cost and get the EOQ:

Economic Order Quantity $=Q^{*}=\sqrt{\frac{2 \mathrm{DS}}{\mathrm{H}}}$

$\mathrm{Q} \quad=$ Number of units per-order

EOQ = Optimum number of units perorder

$\mathrm{D}=$ Annual demand in units for inventory items

$\mathrm{S} \quad=$ Cost for each order

$\mathrm{H} \quad$ = Holding costs per year

Number of orders in a year $=\mathrm{N}=\frac{\mathrm{D}}{\mathrm{EOQ}}$

Time between orders $=\mathrm{T}=\frac{249}{\mathrm{~N}}$

Total ordering cost and holding cost $=\mathrm{TC}=\frac{\mathrm{DS}}{\mathrm{Q}}+\frac{\mathrm{QH}}{2}$

Re Ordering Point $(R O P)=d x L+S S$

Demand per day $=\mathrm{d}=\frac{\mathrm{D}}{\text { Number of work days in a year }}$

Safety stock $(\mathrm{SS})=\mathrm{Z} \times \sigma_{\mathrm{dLT}}$ 


\section{RESEARCH METHODS}

The research that will be done is a quantitative type by doing a calculation of the secondary data of work process results from various ERP/SAP reports. The data collected by direct observation to retrieve the necessary data in place of research is carried out. Population in this research is the entire Stock keetper Unit (SKU) circulating in the warehouse of PT $\mathrm{XYZ}$ inventory as much as 2,498 SKUs. The sampling method used is the purposive by processing total population of 2,498 SKUs using by ABC analysis and FSN analysis to select 10 SKUs that included in Category A and Group F as sample research data. In this research the data analysis used is quantitative analysis using inventory control methods, among others ABC analysis, 3 methods of forecast Moving Averages, Exponetial Smoothing and Least Squares, as well as Economic Order Quantity (EOQ).

Table 3. Calculation Variables

\begin{tabular}{|c|c|c|c|}
\hline Variable & Dimensi & Indikator & Scale \\
\hline \multirow{7}{*}{$\begin{array}{l}\text { Inventory Control } \\
\text { (X) }\end{array}$} & \multirow{3}{*}{ 1. ABC Analysis } & 1. Category A & Interval \\
\hline & & 2. Category B & Interval \\
\hline & & 3. Category $\mathrm{C}$ & Interval \\
\hline & 2. Forecasting & 4. Demand Forecasting & Interval \\
\hline & \multirow{3}{*}{ 3. EOQ } & 5. Ordering Cost & Interval \\
\hline & & 6. Holding Cost & Interval \\
\hline & & 7. Economic Order Quantity & Interval \\
\hline \multirow{3}{*}{$\begin{array}{l}\text { Smooth } \\
\text { Operastion (Y) }\end{array}$} & \multirow{3}{*}{$\begin{array}{l}\text { Inventory Cost } \\
\text { Optimation }\end{array}$} & 8. Data Accuation Improve & Interval \\
\hline & & 9. Demand Forecasting Accuration Improve & Ratio \\
\hline & & 10. Optimum Inventory Cost & Interval \\
\hline
\end{tabular}

\section{CONCLUSION AND SUGGESTION}

\section{Conclusions}

Based on the discussion of the research results it can be concluded:

1. The method of Analysis ABC is able to reduce the difficulty of implementing perfetual Stock Check and improving the accuracy of inventory data.

2. The most effective Forecasting Method used for planning supplies needs is the Exponential Smoothing method.

3. The Economic Order Quantity is able to improve the planning of purchasing supplies in higher level.

\section{Suggestion}

1. The results of this research is giving a consideration to improve the competitive advantage of the in order to face the increasingly stringent business competition in the globalization.

2. The improvements of competitive advantage can be done by implementing control of inventory to achieve the purpose of the right quantity availability of goods at the right time and placed as per the sales needs by applying:

- ABC Analysis

- The Exponential Smoothing Method Forecast

- Economic Order Quantity

3. Making changes also requires the effective Change Management strategy that is a set of processes used to ensure that significant strategic changes in the organization are conducted in a controlled and systematic way to address resistance to change in order to increase the engagement and achievement of organizational objectives. Because many tools and techniques are available for repair but fewer can implement them. This change 
Management strategy can be used as next research material to increase the effectiveness of changes that want to be achieved and increase the success of implementation.

\section{REFERENCE}

Atnafu, D., \& Balda, A. (2018). The impact of inventory management practice on firms' competitiveness and organizational performance: Empirical evidence from micro and small enterprises in Ethiopia.

Devarajan, D., \& Jayamohan, M. S. (2015). Stock control in a chemical firm: combined FSN and XYZ analysis.

Devarajana, D., \& Jayamohanb, M. S. (2015). Stock control in a chemical firm: combined FSN and XYZ analysis.

Eksler, L., Aviram, R., Elalouf, A., \& Kamble, A. (2018). An EOQ Model for multiple products with varying degrees of substitutability.

Guga, E., \& Musa, O. (2015). Inventory Management Through Eoq Model A Case Study Of Shpresa Ltd, Albania.

Heizer, Render, \& Munson. (2017). Operation S Management, Sustainability and Suppli Chain Management - 12 Edition.

Huang, J.-C., Wu, T.-J., \& Lu, Y.-C. C. (2017). Improvement of Inventory Control and Forecast According to Activity-Based Classifications: T Company as an Example.

Kaloji, P. P. (2018). A Study on Inventory Management and Its Impact onProfitability in Foundry Industry at Belagavi,Karnataka.

Kontuš, E. (2014). Management Of Inventory In A Company.

Kritchanchai, D., \& Meesamut, W. (2015). Developing Inventory Management in Hospital.

Kusumastuti, D. Peranan Manajemen Logistik dalam Organisasi Publik.

Mahagaonkar, S. S., \& Kelkar, A. A. (2017). Application of ABC Analysis for Material Management of a Residential Building.

Rangkuti, F. (2000). Manajemen Persediaan.

Ravinder, H., \& Misra, R. B. ((2014). ABC Analysis For Inventory Management: Bridging The Gap Between Research And Classroom.

REM Associates of Princeton. (1999).

Rodrigues, L. L., Oliveira, I. H., Alexandre, M. F., Castorani, R. R., \& Jacubavicius, C. (2015). Stocks Management Through Application Of Demand Forecast Methods: A Case Study.

Shen, H., Deng, Q., Lao, R., \& Wu, S. (2017). A Case Study of Inventory Management in a Manufacturing Company in China.

Sohail, N., \& Sheikh, T. H. (2018). A Study of Inventory Management System Case Study.

Sutawijaya, A. H., \& Marlapa, E. (2016). Supply Chain Management: Analisis Dan Penerapan 
Menggunakan Reference (Scor) Di Pt. Indoturbine. 